DOI: 10.17707/AgricultForest.63.2.03

\begin{abstract}
Alexandru-Claudiu DOBRE, Cristian ANGHELUS, Gabriel NEDEA, Diana SILAGHI, Serban CHIVULESCU ${ }^{1}$
\end{abstract}

\title{
THE CORRELATION BETWEEN DBH AND THE HEIGHT OF SOME FLOOD PLAIN STANDS FROM NATURAL PARK „LUNCA MURESULUI”
}

\begin{abstract}
SUMMARY
On the background of climate changes, in the last period concerns regarding the forest vegetation have increased due to its role in improving the effects of these climatic changes. The stands from meadow have a great importance because they represent habitat and food source for a large variety of living beings. In the last decade, the occupied surface with these types of ecosystem decreased. Research on the influence towards diminishing of these areas is the main purpose of the paper. The research objectives refer to capturing the relationship between main variables of the trees: diameters and heights.

Following research was highlighted a strong relation between those two variables, both through graphical representation and through the values of correlation coefficients (0.69-0.93). The mathematical relationships used in the description of these correlative links caught very well the stands structure, fact indicated by the standard error values (0.05-3.18).

In the case of oak stand, regarding the distribution on variation coefficient of heights in relation with diameters, it has been noticed a greater stability around the $d_{50}$, reference diameter for $h_{50}$ height, from uneven aged stands. This aspect supports the theory from literature, according to which the stands, subject to selection cuttings, the reference diameter of height indicator is $50 \mathrm{~cm}$.

Keywords: meadow forests, uneven-aged forests, oak from meadow, DBHheight relationship, Mures Natural Park.

\section{INTRODUCTION}

On the background of climatic changes, the forest vegetation is a fundamental component for a sustainable management of these ecosystems and those who depend on them (Trettin et al., 2016). In Romania, some of the most sensitive forest ecosystems with a commendable reduction are the flood plain oak stands (Calinovschiși Palaghianu, 2007). This representative diminution is due, in

\footnotetext{
${ }^{1}$ Alexandru-Claudiu Dobre (corresponding author: alexandru_claudiu.dobre@icas.ro), National Institute for Research and Development in Forestry "Marin Drăcea" Bucharest, ROMANIA, Faculty of Biology, University of Bucharest, ROMANIA; Cristian Anghelus, Gabriel Nedea, Diana Silaghi, National Institute for Research and Development in Forestry "Marin Drăcea" Bucharest, ROMANIA; Serban Chivulescu, National Institute for Research and Development in Forestry "Marin Drăcea" Bucharest, ROMANIA, Faculty of Silviculture and Forest Engineering, University of Transilvania, Brasov, ROMANIA

Notes: The authors declare that they have no conflicts of interest. Authorship Form signed online.
} 
general, to the anthropic impact (Stanescu, 1979, Calinovschiși Palaghianu, 2007). In this way, the current researches are of great interest towards protection and conservation of them through a sustainable management.

All the more, the current researches goes on the flood plain of the most important rivers from Romania- Mureș river, these ecosystems are able to fulfil the protection functions of river beds against erosion and the protection against floods of towns or farmland neighbouring river. As well as their importance for the Terra climate and biodiversity, the forest are a major component of rural development which offers protection functions of soil, water and infrastructure, contributing through goods and services in economic and social field(Ojea et al., 2012, Briner et al., 2013, García-Nieto et al., 2013).

At the same time, these researches are part of some multidisciplinary studies included in a project for enlargement of LTER Romania network in forest ecosystems from flood plain (Silaghi, Chisăliță, 2014).

Research purpose was to understand, as detailed, the structure and functional characteristics of flood plain stands, which have in composition, beside the characteristics species of this ecosystem (poplar, common ash etc.) other species, which due the climate changes start slowly to disappear from this area (oak).

Research objectives, are correlated with their purpose, it refers to tying the correlation between the most important trees characteristics, respectively diameter and height.

\section{MATERIALS AND METHODS}

\subsection{Location of permanent plots}

The researches were conducted in Natural Park "Lunca Muresului", situated in the west part of Romania, across Arad andTimiş county (Fig. 1). The occupied surface is 6466,6 ha (37,1\% from all the natural park surface) and contain forest ecosystems with semi natural character, but with small anthropic influences.

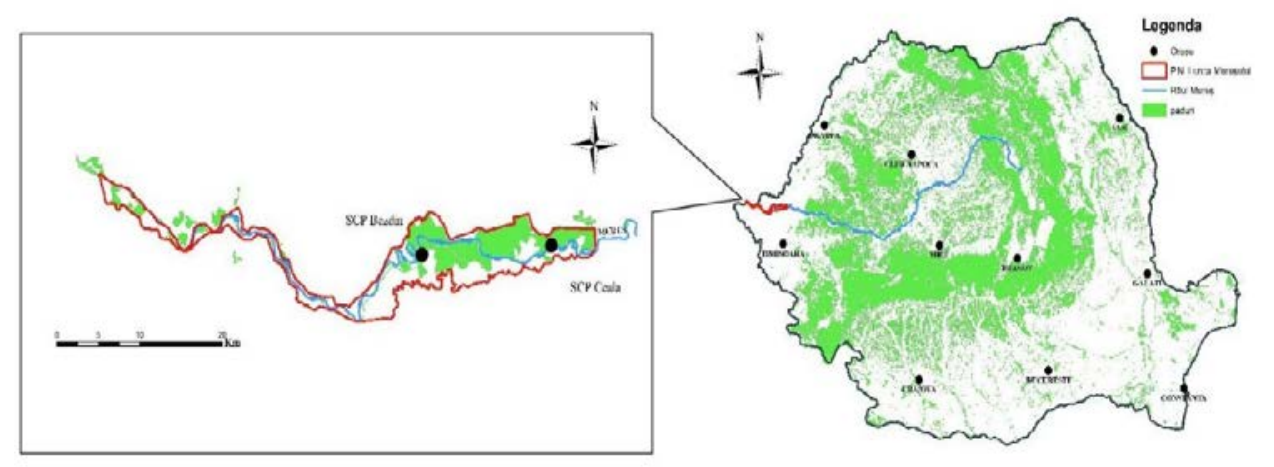

Figure 1: The location of permanent plot in Natural Park Lunca Muresului and Romania territory (EEA, 2000, MMP, 2014). 
These studies were conducted in the project „The action of climate changes and other stress factors on the forest ecosystems situation from Natural Park" Lunca Mureșului", achieved in the collaboration between INCDS” Marin Drăcea" and National Forest Administration "Romsilva" from Romania. Within the research were placed two experimental plots, with square form (100x100m) with an area of 1ha, located across the yield management unit I Bezdin and V Ceala of Iuliu Moldovan forest district (FD) from County forest administration (CFA) (Table 1). To permanent research plots location (PRP) has been taken into account the degree of representation for flood plain ecosystems and the field configuration.

Table 1: The principal indicators of sample plots characterization

\begin{tabular}{|c|c|c|c|}
\hline \multicolumn{2}{|c|}{ Permanent research plod (PRP) } & PRP Bezdin & PRP Ceala \\
\hline \multicolumn{2}{|c|}{ County (CFA) } & Arad & Arad \\
\hline \multicolumn{2}{|c|}{ Forest District (FD) } & Iuliu Moldovan & Iuliu Moldovan \\
\hline \multicolumn{2}{|c|}{ Yield management unit (UP) } & UP. I Bezdin & UP. V Ceala \\
\hline \multicolumn{2}{|c|}{ Compartment (u.a.) } & $33 \mathrm{C}$ & $17 \mathrm{~L}$ \\
\hline \multicolumn{2}{|c|}{ Forest formation } & Mixed foliage forest & Mixed foliage forest \\
\hline \multicolumn{2}{|c|}{ Principal species } & Oak & Poplar \\
\hline \multicolumn{2}{|l|}{ Age* (years) $^{*}$} & 105 & 30 \\
\hline \multicolumn{2}{|l|}{ Structure } & Uneven-aged & Uneven-aged \\
\hline \multicolumn{2}{|l|}{ Alt. (m) } & 96 & 105 \\
\hline \multirow{2}{*}{ Coordinates } & Lat & $46^{\circ} 08^{\prime} 07^{\prime \prime} \mathrm{N}$ & $46^{\circ} 09^{\prime} 03^{\prime \prime} \mathrm{N}$ \\
\hline & Long & $21^{\circ} 00^{\prime} 32^{\prime \prime} \mathrm{E}$ & $21^{\circ} 12^{\prime} 37^{\prime \prime} \mathrm{E}$ \\
\hline
\end{tabular}

* Extracted from Management Plans

\subsection{Research method}

In the permanent research plots PRP Bezdin and PRP Ceala were taken into the inventory all the trees with diameter at breast height (d) greater than 80 $\mathrm{mm}$, have been achieved in this way the main characteristics of trees (diameter, height, quality class, cenotic position etc.). The diameter (d) was measured with measuring-tape, materializing the place on tree with paint towards any reviews, and height of trees with the help of ultrasonic hypsometer Vertex IVfor all the trees in inventory (Badea, 2008). Furthermore, was determined the position class considering the stand floor and the quality class considering work wood proportion from total height of tree (Giurgiu, 1979);

The information obtained following inventory were registered in a typified sheet, after, this sheet was used for developing a database and for calculation.

In the case of structure analysis of stands and the relationships between dendrometric characteristics were taken into account the main species from this permanent research plots. Thus, the main species which form the PRP composition are: oak (Quercusrobur), common ash (Fraxinus excelsior), common maple (Acer campestre), white poplar (Populus alba) and elm tree (Ulmus minor). The relationship between the diameter at breast height and height have a great importance in stand characterization (Zhang, 1996). For 
highlighting the correlation between the diameter and height (Giurgiu,1999, Giurgiu et al., 2004) was calculated the variation coefficient of height and after was represented graphically in relation with the diameter (d). To draw the height curve was tested a series of mathematical relations, which was used in the past for describing the connection between those two characteristics of the stands from the permanent research plots ( $d$ and $h$ ). The most suitable equations to describe the diameter - height relation were in accordance with the specific methodology (Giurgiu et al., 2004, Mahmut, 2004, Zhang, 1997) and the standard error have small values with a normal curve form. In the wake of testing more biometric equations, the most suitable for stands characterization, from permanent research plots, turn out to be the following:

$$
\begin{aligned}
& h=a_{0}+a_{1} \log d \\
& h=a_{0}+a_{1} d+a_{2} d^{2}(2) \\
& \log h=a_{0}+a_{1} \log d+a_{2} \log ^{2} d(3)
\end{aligned}
$$

where: $d$-diameter at breast height $(\mathrm{cm})$;

$h$ - tree height (m);

$a_{0}-a_{2}$-coefficients for regression equations, corresponding each species(Giurgiu et al., 2004).

In the process of applying the mathematical models, were used the packets Stats (Bates and Chambers, 1992), Base and graphics (Chambers and Hastie, 1992) of the program $R$.

\section{RESULTS AND DISCUSSION}

For permanent research plots characterization was determined a series of statistical indicators with a dependency towards stands structure. In general, was calculated limit values, arithmetical mean diameter, mean height and standard deviation (Table 2).

Table 2: Main characteristics of stands from permanent research plots

\begin{tabular}{|l|l|c|c|c|c|c|c|}
\hline $\begin{array}{c}\text { Permanent } \\
\text { research } \\
\text { plots }\end{array}$ & Characteristic & $\begin{array}{c}\text { Number } \\
\text { of tree } \\
(\mathrm{N})\end{array}$ & $\begin{array}{c}\text { Min } \\
(\text { Min) }\end{array}$ & $\begin{array}{c}\text { Max } \\
(\text { Max })\end{array}$ & $\begin{array}{c}\text { Average } \\
(\overline{\mathrm{X}})\end{array}$ & $\begin{array}{c}\text { Standard } \\
\text { deviation } \\
(\mathrm{s})\end{array}$ & $\begin{array}{c}\text { Variance } \\
\left(\mathrm{s}^{2}\right)\end{array}$ \\
\hline \multirow{2}{*}{$\begin{array}{l}\text { PRP } \\
\text { Bezdin }\end{array}$} & Diameter $(\mathrm{cm})$ & 562 & 3 & 88 & 22,13 & 19,43 & 377,74 \\
\cline { 2 - 8 } & Height $(\mathrm{m})$ & 562 & 2 & 45 & 17,14 & 11,77 & 138,65 \\
\hline \multirow{2}{*}{ PRP Ceala } & Diameter $(\mathrm{cm})$ & 602 & 3 & 48 & 17,09 & 9,48 & 90,02 \\
\cline { 2 - 8 } Total & Height $(\mathrm{m})$ & 602 & 2 & 34 & 17,27 & 6,98 & 48,85 \\
\cline { 2 - 8 } & Diameter $(\mathrm{cm})$ & 1164 & 3 & 88 & 19,55 & - & - \\
\cline { 2 - 8 } & Height $(\mathrm{m})$ & 1164 & 2 & 45 & 17,20 & - & - \\
\hline
\end{tabular}

These two areas have close values in what concern the mean height of tree with a value of $17,20 \mathrm{~m}$, and standard deviation, it fit in the interval 9,48 (PRP Ceala) - 19.43 (PRP Bezdin) in the case of diameters and for height, standard deviation have a specific range 6,98 (PRP Ceala) and 11,77 m(PRP Bezdin). The studied stands have a similar structure, with small exceptions, PRP Ceala shows a major homogeneity as regard the diameters and also the height compared to PRP 
Bezdin. In what concern the statistical parameters of central tendency, was determined the arithmetical mean diameter which reaches the value of 22,13 cm for PRP Bezdin and 17,09 for PRP Ceala. The minimum and maximum, characteristics of this areas have defined limits by the intervals 2-88 $\mathrm{cm}$ for diameters, and 2-45 $\mathrm{m}$ for heights, highlighting a great diversity, due to unevenaged structure of stands which are in the permanent research plots.

The relationships between diameter and height of tree is highlighted by the connection between the most fundamental characteristics of stand, diameter and height, used for growth describing and forest good development (Meng et all, 2008). In the past, this connection was studied by various foreign researchers (Huang et al., 1992, Peng et al., 2001, Calama and Montero, 2004, Temesgensi Gadow, 2004, Sharma and Parton, 2007, Temesgen et al., 2008), but also by Romanian researchers (Prodan, 1965, Giurgiu, 1969, 1974, 1999, 2004). The graphical representation of heights curves has, in most of the cases, an ascendant bearing, which linearize gradually, following the "normal, biological motivated" form from literature (Giurgiu, 1999, 2004) (Fig. 2).

In many instances, the most suitable relationship for describing the connection between diameters and heights was relation (3) used forPRP Ceala Common ash, PRP Ceala - White poplar and PRP Ceala - Elm tree.In the past, this equation was used with success for describing the flood plain stands (Trettinand Stringer, 2016).

Relation (2), likewise, has registered good results, curve bearing being characteristic for relationship diameter-height. The connection between those two variables was represented through the value of correlation coefficient, and to check if the used equation was the most suitable it was calculated the value of standard deviation (Table 3).

Table 3: Main statistical parameters from permanent research plots

\begin{tabular}{|c|c|c|c|c|c|c|}
\hline \multirow{2}{*}{$\begin{array}{c}\text { Statistical } \\
\text { parameters }\end{array}$} & \multicolumn{3}{|c|}{ PRP Bezdin } & \multicolumn{3}{c|}{ PRP Ceala } \\
\cline { 2 - 7 } & Ash & $\begin{array}{c}\text { Common } \\
\text { Maple }\end{array}$ & Oak & $\begin{array}{c}\text { Common } \\
\text { ash }\end{array}$ & $\begin{array}{c}\text { White } \\
\text { Poplar }\end{array}$ & Elm \\
\hline $\begin{array}{c}\text { Standard } \\
\text { deviation }\end{array}$ & 2,35 & 3,18 & 0,09 & 0,07 & 0,05 & 0,08 \\
\hline $\begin{array}{c}\text { Correlation } \\
\text { coefficient (r) }\end{array}$ & 0,71 & 0,68 & 0,82 & 0,89 & 0,81 & 0,93 \\
\hline
\end{tabular}

Thus, can be observed that the equations used for describing the relationship diameter-heights follows the criteria from literature (Giurgiu et al., 2004) with regard to standard error, having values between 0,05 and 3,18.In what concern the correlation between this two variables, can be appreciated that in many instances have a strong connection (PRP Bezdin - Oak, PRP Ceala Common ash, PRP Ceala White poplar and PRP Ceala - Elm). PRP Bezdin Common ash and PRP Bezdin Common Maple, don't follows this trend, them have a connection with medium intensity between variables. This aspect is due to 
lower participating proportion of these species in forest stand composition. Also, these values can be found in the determined limits in other studies, respectively 0,6 and 0,9 (Giurgiu, 1979).
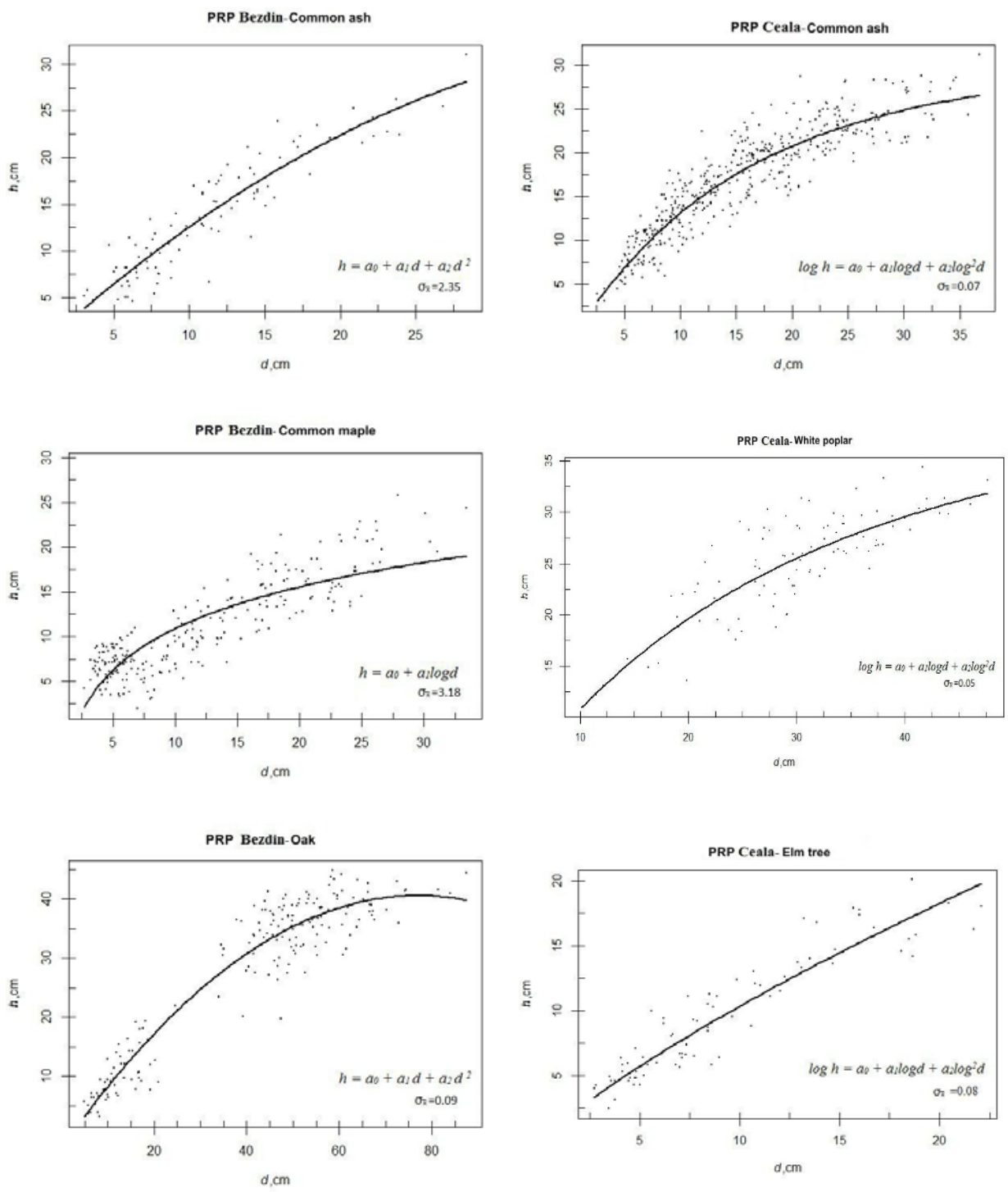

Figure 2: The correlation between diameter and height for permanent research plot

Further to highlight clearer the intensity of diameter-height connection, it was passed to graphical representation of height variability, expressed through variation coefficient $\left(\mathrm{S} \%_{\mathrm{h}}\right)$ in relation with the diameter (Fig. 3). 

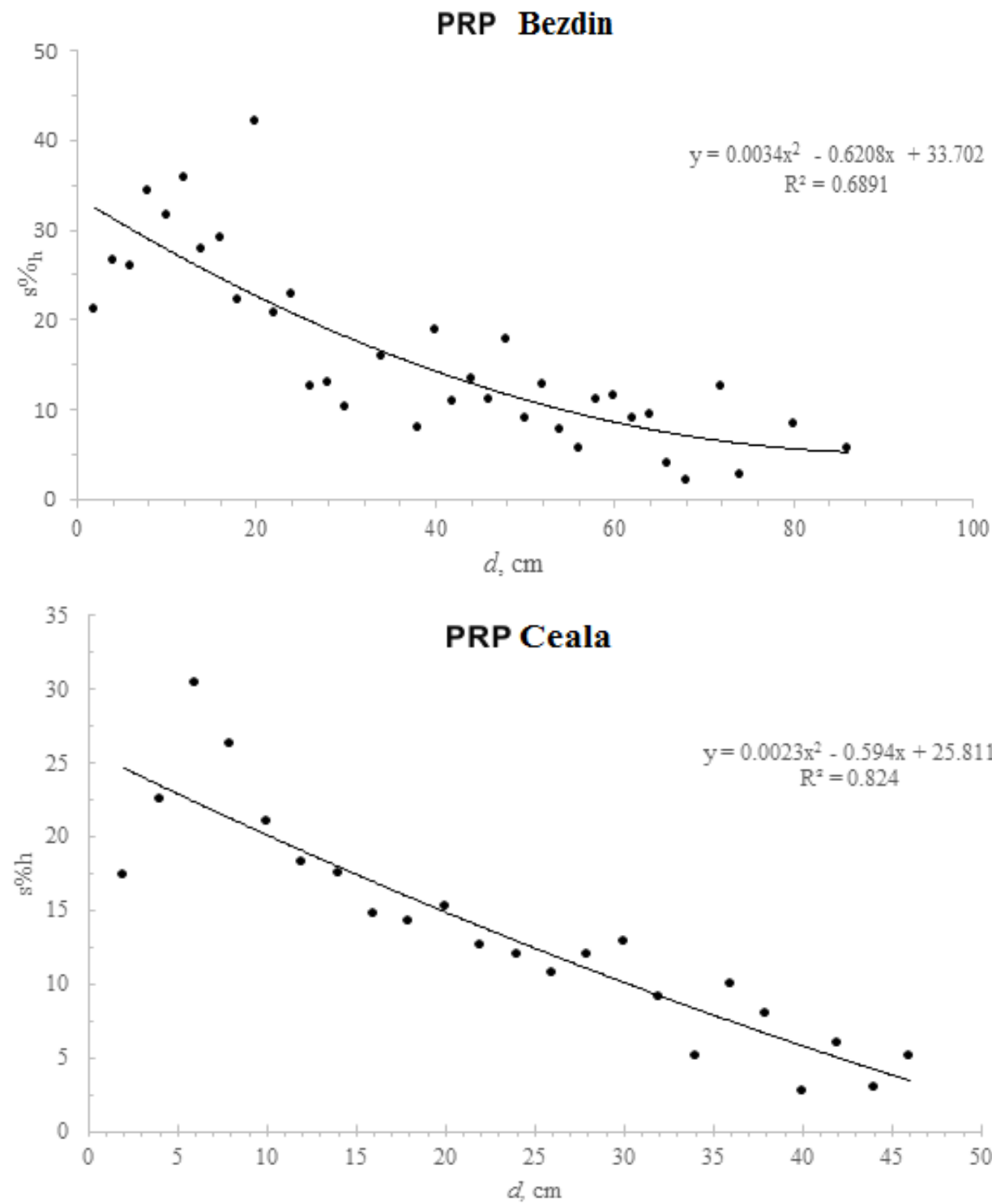

Figure 3: Distribution of variation coefficient for height in relation with diameter from permanent research plots

It can be observed that the studied stands follow the lawfulness according to which the stands with heliophilous species (oak, sessile oak, poplar etc.) have small values for variation coefficient of heights (Giurgiu, 1999). For the stand from PRP Bezdin, where can be found trees with large diameters can be observed a small stability near the 50 ' $\mathrm{cm}$ diameter $\left(\mathrm{d}_{50}\right)$, reference diameter for indicator height $h_{50}$, characteristic for uneven-aged stands, coming to support 
the hypothesis from literature according to which the stand shows a maximum stability at the level of $d_{50}$ (Chivulescu et al, 2014). In accordance with the same hypothesis, after this reference diameter, the variability should grow, but in the case of stand from PRP Bezdin, it does not happen. This aspect is due to the old age of stand (Giurgiu, 1999), respectively105 years (I.C.A.S., 2012), number of trees from the higher categories considerable reducing, make it this way a instability in the structure of stands.

In the case of stand PRP Ceala, it can be observed that the distribution curve form of variation coefficient for height in relation with the diameters is exponentially negative, where many value can be found in the small categories of diameters, this fact is explained by the inhomogeneity of stands due the presence of more stands elements (Ichim, 1968; Assman, 1970; Roibu, 2010).

Also through all mentioned above, can be noticed the gradual deletion of oak from pond stand composition, making possible in the future a complete deletion of this kind of ecosystems. Most likely, the cause of these strikes from natural cycle of these ecosystem is due to climate change in the last period. Some of these aspects it would be clarified in the following studies regarding stands auxology and the influence of disruptors factors, like climate effects on those.

\section{CONCLUSION}

In the last period, a considerable drop has developed of the forest stands from flood plain rivers, and a detailed research regarding this depreciation is absolutely necessary to understand the cause of it. The actual studies are a part from a series of multidisciplinary researches, conducted in an institutionalized background, highlighting in this way the enhancement of researchers and decisional forums preoccupation regarding this subject.

The researches were conducted in two uneven-aged stands of oak and white poplar from Mureș flood plain, situated across Natural Park "Lunca Mureșului". The research methods were based on enshrined methodologies in forestry domain, but also modern ways like automatically processing of data. In this way, in shorter time were tested a series of regression equations for the relationships diameters-heights, finally choosing the most suitable solution, taking into account all validation criteria.

Thus, were determined the main statistical parameters, highlighting, with small exceptions, the similarity of stands structure. The form of the most heights curves is "a normal one, biological motivated" taking into account in this way the lawfulness regarding their form from literature. Also at these stands was remarketed a strong link between diameters and height, fact highlighted through the values of the correlation coefficient, with a range between 0,68 and 0,93. Small strikes from this strong link were possible due to the lower participating proportion of these species in the stand total composition. 
The used equations for describing the relation between those two variables (diameters and heights) were most suitable, fact proven by the values of standard error, ranging 0,05 and 3,18.

In the case of the stand from PRP Bezdin, were can be found also trees with bigger diameters, was identified a small stability around diameter $d_{50}$, reference diameter for height $\mathrm{h}_{50}$, demonstrating in this way the theory according to the fact that in stands with selection system, the reference diameter for indicator height is that one previously mentioned. According to the same theory the variability should grow after this diameter, aspect not proven in the case of the studied stands in this paper, due the lack of superior diameter. This aspect is due to the old age of stand and climate change from the last period, which have a great influence on the trees vitality located in the permanent research plots.

For materialization of these researches in the future will be set more ample studies regarding the trees auxology and the influence of climatic factors on these ecosystems.

\section{REFERENCES}

Assman, E., 1970. The principles of forest yield study. Trad. Inglês: SH Gardiner.

Badea, O.,2008: Manual privindmetodologia de supravegherepetermen lung a stăriiecosistemelorforestiereaflate sub acţiuneapoluăriiatmosfericeşimodificărilorclimatice , EdituraSilvică, Voluntari, 98p.

Bates, D. M. \&Chambers, J. M. (1992) Nonlinear models. Chapter 10 of Statistical Models in S, Editors J. M. Chambers and T. J. Hastie, Wadsworth \& Brooks/Cole

Briner, S., et al., A., 2012. Assessing the impacts of economic and climate changes on land-use in mountain regions: A spatial dynamic modeling approach. Agriculture, Ecosystems \& Environment, 149, pp.50-63.

Calama, R. \&Montero, G., 2004. Interregional nonlinear height diameter model with random coefficients for stone pine in Spain. Canadian Journal of Forest Research, 34(1), pp.150163.

Chambers, J.M. \& Hastie, T.J., 1991. Statistical models in S. CRC Press.

Chivulescuet et al., 2016. Structural Features of virgin beech forests in Semenic mountains. The dynamic structure of virgin beech forest P20 Semenic between 2005-2013.

Clinovschi, F.\&Palaghianu, C., 2007. Studiuasuprastructuriivegetatieilemnoase din RezervatiaZamostea-Lunca. AnaleleUniversitatii Stefan cel Mare SuceavaSectiuneaSilvicultura, 9(1), pp.19-28. ,

García-Nieto et al., 2013. Mapping forest ecosystem services: from providing units to beneficiaries. Ecosystem Services, 4, pp.126-138.

EEA ,2000. Corine Land Cover, European Environment. Agency (EEA). Available at: http://www.eea.europa.eu/data-and-maps/data/corine-land-cover-2006-raster-2

Giurgiu, V., 1969. Dendrometrie. Ed. Agro-Silvică. 1974,

Giurgiu, V., 1979: Dendrometrics and forestry auxology, Editura Ceres, Bucureşti, 692p.

Giurgiu, V., 1999: Corelaţiadintreînălţimileşidiametrelearborilorînarboreteleechieneşipluriene din România, Giurgiu 1999, Silvologie, vol. II, EdituraAcademieiRomâne, Bucureşti,1999, 9$64 \mathrm{p}$.

Giurgiu, V.,2004: Metodeşitabeledendrometrice, Editura Ceres, Bucureşti, 575p.

Huang, S., Titus, S.J. and Wiens, D.P., 1992. Comparison of nonlinear height-diameter functions for major Alberta tree species. Canadian Journal of Forest Research, 22(9), p.1297-1304.

I.C.A.S., 2012. Amenajamentul silvic U.P. V Bezdin 
Meng, S.X., et al.,2008. Wind speed and crown class influence the height-diameter relationship of lodgepole pine: nonlinear mixed effects modeling. Forest Ecology and Management, 256(4), pp.570-577.

MinisterulMediuluișiPădurilor (MMP), 2014, Limitele GIS ale ariilornaturaleprotejate de interes national /international, data available through next link: http://www.mmediu.ro/articol/ariinaturale-protejate/33

Ojea, E., Martin-Ortega, J. \&Chiabai, A., 2012. Defining and classifying ecosystem services for economic valuation: the case of forest water services. Environmental Science \& Policy, 19, pp.1-15.

Peng, C.et al., 2001. Developing and validating nonlinear height-diameter models for major Tree species of Ontario's boreal forests. Northern Journal of Applied Forestry, 18(3), pp.87-94.

Prodan, M., 1965. Holzmesslehre (p. 644). JD Sauerländer.

Radu, I., 1968. Variabilitateacaracteristicilordendrometrice ale arborilor din arboretele de molidexploatabileşi de tip regulat.Revistapădurilor

Roibu, C.C., 2010. Biometrics and dendrochronological researches in beech forests from Suceava Plateau at Eastern limit of the European areal (Doctoral dissertation, PhD thesis," Ştefancel Mare" University, Suceava 274 p.

Temesgen, H. \&Gadow, K.V., 2004. Generalized height-diameter models-an application for major tree species in complex stands of interior British Columbia. European Journal of Forest Research, 123(1), pp.45-51.

Temesgen, H., et al., 2008. Analysis and comparison of nonlinear tree height prediction strategies for Douglas-fir forests. Canadian Journal of Forest Research, 38(3), pp.553-565

Trettin, C.C., et al., 2016. Composition, biomass and structure of mangroves within the Zambezi River Delta. Wetlands Ecology and Management, 24(2), pp.173-186.

Sharma, M. \& Parton, J., 2007. Height-diameter equations for boreal tree species in Ontario using a mixed-effects modeling approach. Forest Ecology and Management, 249(3), pp.187-198.

Silaghi, D.,\&Chisaliță,I. 2014. Acțiuneaschimbărilorclimaticeși a diferițilorfactori de stress asuprastăriiecosistemelorforestiere din Parcul Natural LuncaMureșului - 14.17. Raportştiinţificanual

Stănescu, V., 1979. Dendrologie. EdituraDidacticăşiPedagogică.

Zhang, L.,1996: Cross-validation of Non-linear Growth Function for Modelling Tree HeightDiameter Relationships, Annals of Botany 79, 251-257p., 1997. 